Photovoltaic

https://doi.org/10.52825/thwildauensp.v1i.3

(C) Authors. This work is licensed under a Creative Commons Attribution 4.0 International License

Published: 15 June 2021

\title{
Simulation study of perovskite cell performance in real conditions of sub-Saharan Africa
}

\author{
Essodossomondom Anate ${ }^{1}$, N'Detigma Kata ${ }^{1,2}$, Hodo-Abalo Samah ${ }^{1}$, Amadou Seidou Maiga $^{2}$ \\ ${ }^{1}$ Faculté des Sciences et Techniques, Université de Kara, Togo. \\ ${ }^{2}$ Laboratoire Électronique, Informatique, Télécommunication et Énergies Renouvelables, \\ Saint-Louis, Sénégal
}

\begin{abstract}
Perovskite is certainly the material of the future of photovoltaics for terrestrial applications. With high efficiencies and advances in stability, perovskite solar cells, modules and mini-modules have already made their appearance in the laboratory and are being tested under real-world conditions to evaluate their real performance. In our study, we predict the performance of perovskite-based photovoltaic panel technology under the conditions of the Sub-Saharan African region by simulation. We started from the current-voltage characteristic of a real perovskite-based module to extract the cell parameters through MATLAB analysis software. These parameters were used to model a cell and then a module in the LTSpice XVII software for simulation. The impact of temperature is studied to evaluate the performance ratio (PR) of a clear day. This study allowed us to evaluate the PR of the perovskite solar module. Displaying PR reaching $90 \%$, perovskite is a future candidate with high potential in the list of the most suitable technologies for our sub-region.
\end{abstract}

Keywords: PV module, perovskite, simulation, extraction, performance ratio.

\section{Introduction}

This study is situated in the context of forecasting photovoltaic production in real subSaharan conditions. The challenge is to evaluate the influence of climatic factors, in particular temperature, on the photovoltaic performance of a perovskite-based solar photovoltaic module. To ensure the effectiveness of this new technology of photovoltaic panels in the sub-region, it is important to estimate their production in real conditions compared to standard test conditions (STC; $25^{\circ} \mathrm{C}$ and $\mathrm{AM} 1.5 \mathrm{G}$ with $1000 \mathrm{~W} / \mathrm{m}^{2}$ ).

Considered as the "black gold" [1] for photovoltaic cells, the perovskite-based cell reached in 2020 an efficiency of $25.5 \%$ [2] in laboratory. The ease of its synthesis, its low production cost and its integration to various substrates make this technology one of the most accessible to a wide range of users. The crucial issue is its industrialization. Perovskite degrades at temperatures above $40^{\circ} \mathrm{C}$ and is soluble in water [1]. Several studies on these two aspects have been done and are being actively pursued: the introduction of 2methylbenzimidazole $(\mathrm{MBIm})$ by $\mathrm{C}$. Longeaud between the electron transport layer (ETL) $\mathrm{SnO}_{2}$ and the perovskite layer as a passivating layer has improved the stability of the cell [3], S. Sonmezoglu et S. Akin showed that the introduction of Triethyl Citrate (TEC) between the perovskite and PCBM forming the PCBM/TEC retained up to $84 \%$ of the cell performance after 1000 hours of exposure without encapsulation [4]. The improvement of the strontium titanate $\left(\mathrm{SrTiO}_{3}\right)$ electron transport layer by M. Neophytou et al. also shows this [5] etc. At present, perovskite-based modules/mini-modules are available in laboratories with yields, for a small module, of $17.9 \%$ (Panasonic) in 2020 [2] [6]. The same company having reached in May 2019 an efficiency of $16.1 \%$ with a module of 55 cells [7]. All these very encouraging results show the progress made in terms of stability and efficiency. This technology is 
eagerly awaited to prove itself in real-life conditions and will soon appear on the world market. In view of all this, it seems obvious to foresee the efficiency of the perovskite solar cell technology in real conditions in the Sub-Saharan African zone.

We study the impact of temperature on the performance and the performance ratio of the perovskite solar cell in the climatic conditions of Sub-Saharan Africa. The results are presented and discussed in this paper.

\section{Methodology}

Figure 1 presents the flow chart of the method adopted to conduct our study.

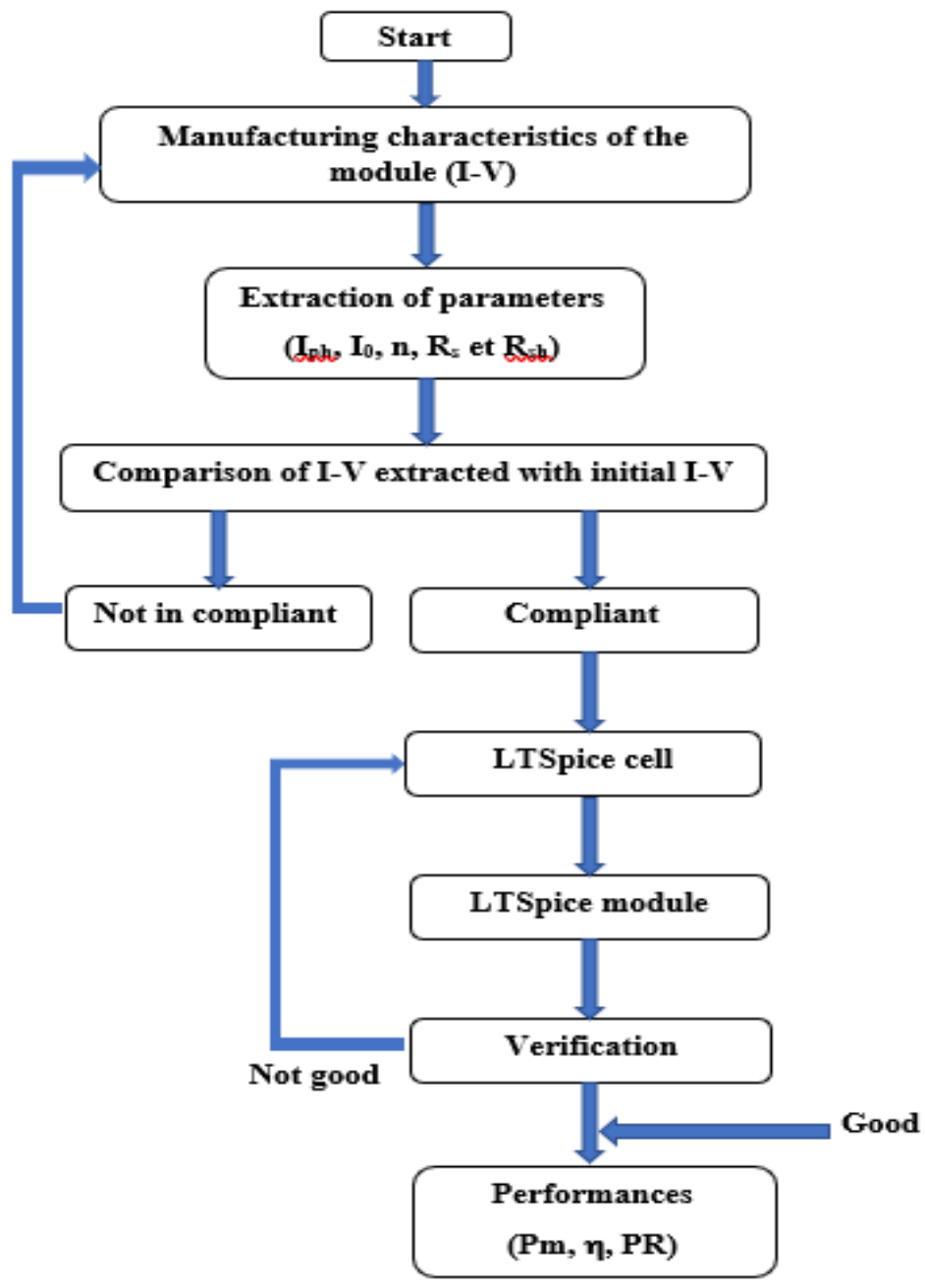

Figure 1. Organization chart of the study

From the current-voltage characteristic of the manufacturer Panasonic (Table 1.) [7], we extracted the data of the one-diode model with five parameters $I_{p h}, I_{0}, n, R_{s}$, and $R_{s h}$, respectively the photo-generated current, saturation current, ideality factor, series resistance and the parallel resistance to carry out our study. The hybrid Levenberg-Marquardt-analytical algorithm proposed by Kata et al. [8] is used to extract these parameters. This algorithm combines the analytical [9] and empirical method to calculate the initial values needed by the Levenberg-Marquardt algorithm making it not only fast and robust but also accurate as shown in [8]. 
Table 1. Manufacturing characteristics of the module

\begin{tabular}{|l|l|}
\hline Open circuit voltage of the module (Voc) & $57.3 \mathrm{~V}$ \\
\hline Short circuit current (Isc) & $321 \mathrm{~mA}$ \\
\hline Module efficiency $(\eta)$ & $16.1 \pm 0.5 \%$ \\
\hline Fill factor (FF) & $70.3 \%$ \\
\hline Module area (S) & $802 \mathrm{~cm}^{2}$ \\
\hline
\end{tabular}

At the end of the extraction the algorithm plots the I-V characteristic corresponding to the extracted data and compares it with the initial I-V characteristic. The algorithm resumes the extraction if there is no conformity of the new I-V characteristic with the initial one. In case of conformity, the data are collected to go to the next step.

This new step consists in modeling a photovoltaic cell in the LTSpice software. The algorithm at the beginning is adapted to the electrical model of the cell with one diode (figure 2.), it is thus this model which will be made in LTSpice, model which we call the "LTSpice cell". This model is shown in Figure 3. Using this model, the current delivered by the cell to a load is given by the equation (1).

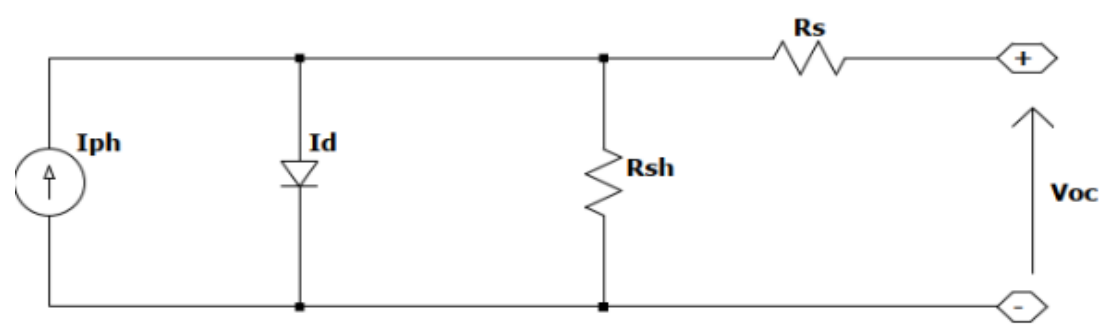

Figure 2. Electrical model equivalent to a diode of a solar cell

$$
I=I_{p h}-I_{0}\left[\exp \left(q \frac{V_{C e l l}+I_{C e l l} R_{S}}{n k_{B} T}\right)-1\right]-\left(\frac{V_{C e l l}+I_{C e l l} R_{S}}{R_{s h}}\right)
$$

Where $I_{p h}$ is the photo-generated current, $I_{0}$ the saturation current, $n$ the ideality factor, $T$ the temperature of the cell, $q$ the elementary charge $\left(1,602 * 10^{-19} \mathrm{C}\right), V_{\text {Cell }}$ the voltage at the terminals of the cell and $k_{B}$ the Boltzmann constant $\left(1,38^{*} 10^{-23} \mathrm{~J} /{ }^{\circ} \mathrm{K}\right)$.

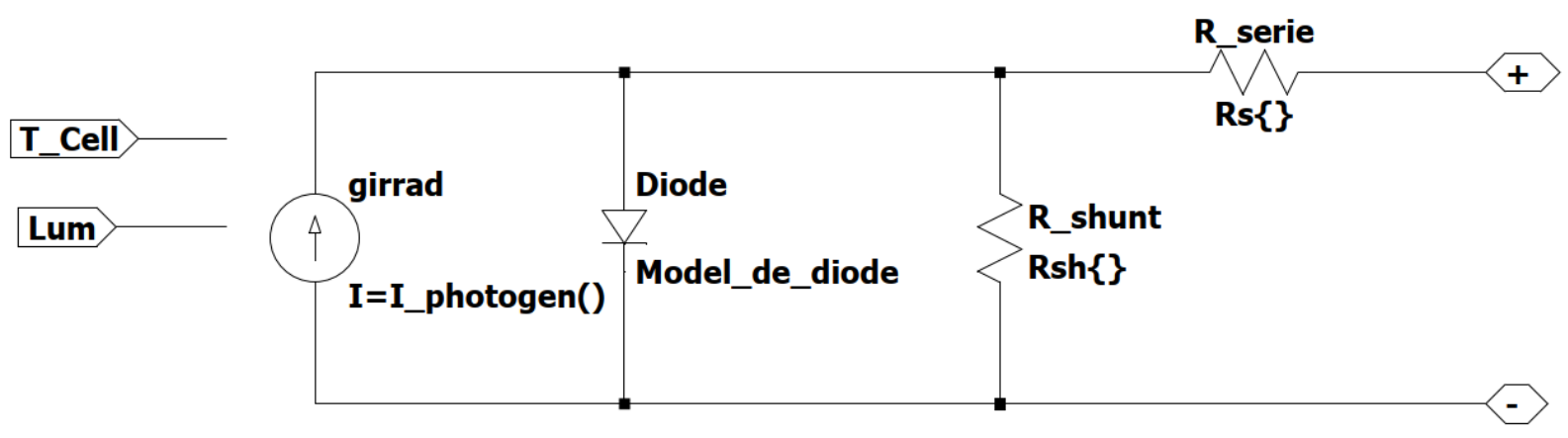

Figure 3. Behavioral model of a photovoltaic cell under LTSpice.

As the maximum power and the arrangement mode were not given, we obtained them (Table 2 ) by using the relation (2) for the maximum power and the relation (3) for the cell arrangement mode.

$$
\eta_{S T C}=p_{m} / s_{\text {Module* }} G_{S T C}
$$




$$
\left\{\begin{array}{l}
\mathrm{I}_{\mathrm{ph}}=\mathrm{N}_{\mathrm{p}} * \mathrm{I}_{\mathrm{scCell}} \\
\mathrm{V}_{\mathrm{oc}}=\mathrm{N}_{\mathrm{s}} * \mathrm{~V}_{\mathrm{ocCell}}
\end{array}\right.
$$

Table 2. Module details

\begin{tabular}{|l|l|}
\hline Maximum power $(\mathrm{Pm})$ & $12.9 \mathrm{~W}$ \\
\hline Arrangement of the cells & Serial \\
\hline
\end{tabular}

The LTSpice cells are then connected in series to form an LTSpice module.

It is in this module that we introduce the temperature and irradiance measurements. The measurements are made during a clear day with a measurement time step of 5 minutes on which we assume that the measured value is a constant.

\section{Results and discussion}

The real performance $\left(\eta_{\text {real }}\right)$ of the LTSpice module is determined for each measurement of the day using equation (4). Like the yield, the performance ratio allows the comparison of performances between different technologies and also within the same technology with respect to the conditions in which they are installed. It is defined as the ratio between the real performance under real conditions and the performance under STC conditions $\left(\eta_{S T C}\right)$ in equation (5).

$$
\begin{aligned}
& \eta_{\text {réel }}=\frac{P_{m \text { réel }}}{S * G_{\text {réel }}} \\
& \mathrm{PR}=\frac{\eta_{\text {réel }}}{\eta_{S T C}}
\end{aligned}
$$

Figure 4 shows the evolution of the performance ratio, temperature and irradiance as a function of time of day.

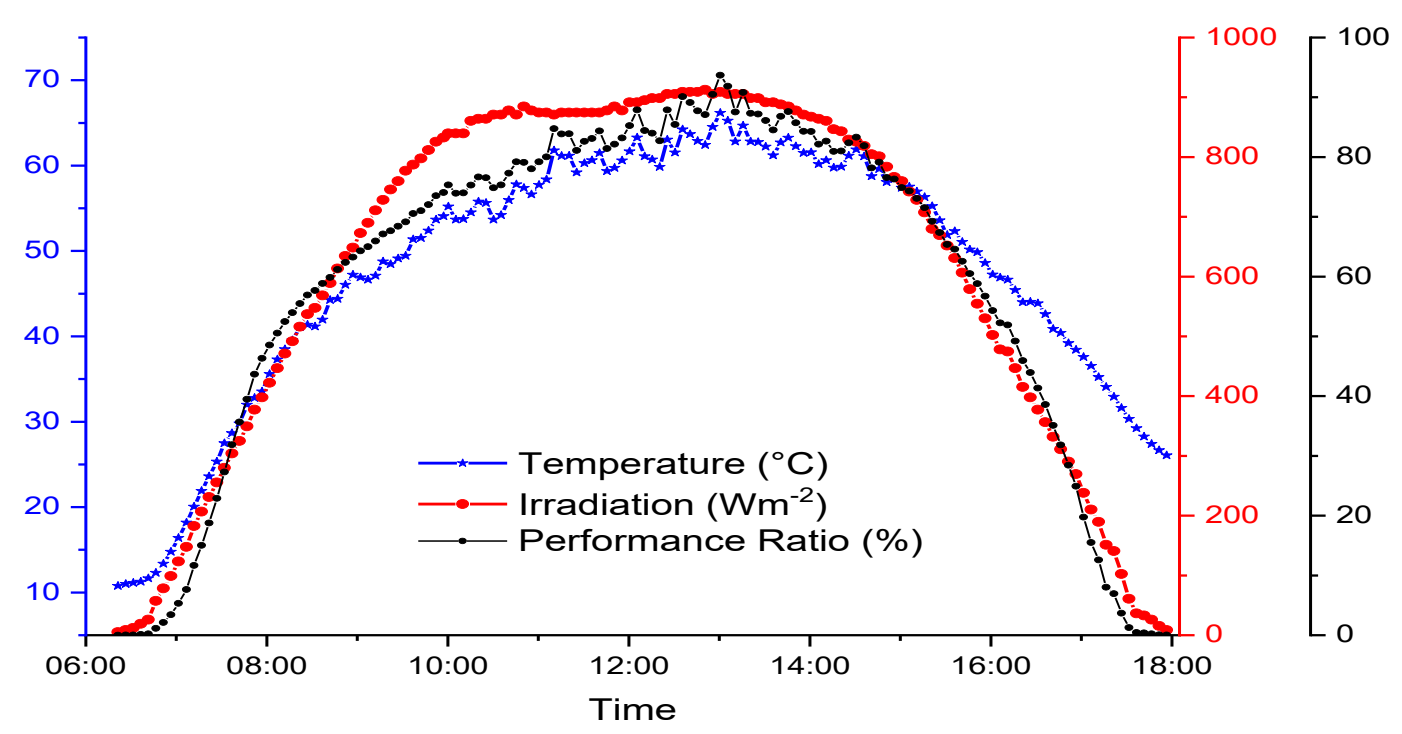

Figure 4. Evolution of the performance ratio during the day under clear sky 
We can notice through the graph of figure 4 a performance ratio exceeding $70 \%$ between 10 am and $3 \mathrm{pm}$, period on which often appear high irradiation and high temperatures of the day. The highest PR is obtained at the highest temperature point of the day with of course an irradiation close to the maximum of the day. This means that the perovskite-based solar cell shows only a small decrease in efficiency with high temperature and thus agrees with the finding of Tress et al. in [10]. These results seem obvious when we know that perovskite is not very sensitive to temperatures above ambient [11]

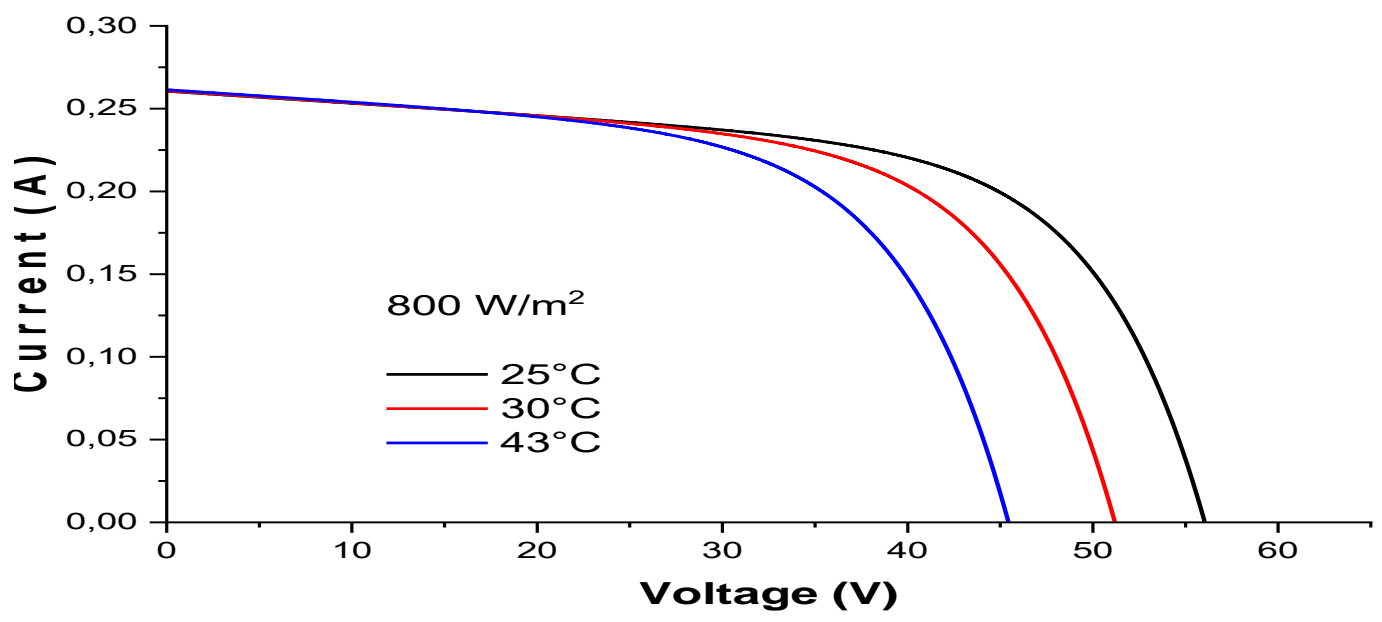

Figure 5. I-V curve showing the effect of temperature

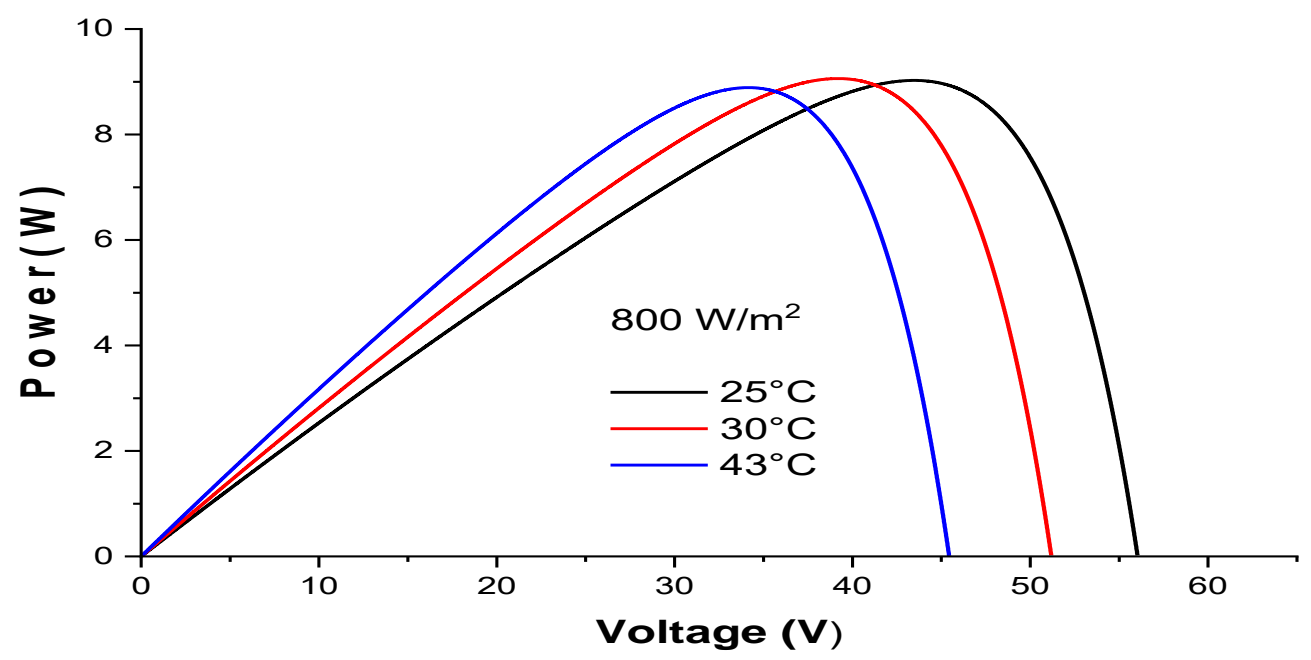

Figure 6. P-V curve showing the effect of temperature

We show here the effect of temperature on the voltage and also on the power. By fixing the irradiation we see that it is the voltage that is responsible for the decrease in performance when the temperature increases in the cell. The current remaining constant and a decreasing voltage leads to a decrease of the power according to equation (6).

$$
\mathrm{P}_{\mathrm{m}}=\mathrm{V}_{\mathrm{m}} * \mathrm{I}_{\mathrm{m}}
$$


As shown by J. A. Schwenzer et al., the voltage decreases with temperature. This is justified by a negative temperature coefficient of the voltage. [12] [13]

\section{Conclusion}

In this paper we have evaluated the performance of a perovskite based photovoltaic module in the climatic conditions of Sub-Saharan Africa by simulation. We used the LevenbergMarquardt-analytical hybrid extraction method proposed by Kata et al. to retrieve the data that allowed us to model a LTSpice PV module. Thus, we have collected the performances that we compare with those of the STC conditions. These results are inferior to those of STC conditions but remain encouraging for a young and very promising technology. With low temperature coefficients, perovskite is a potential future candidate of the most suitable technologies for our sub-region

\section{References}

[1] Jemli K. Synthése et auto-assemblage de molécules de pérovskite pour la photonique et le marquage. Université Paris-Saclay; Faculté des Sciences de Bizerte (Tunisie); 2016.

[2] Green M, Dunlop E, Hohl-Ebinger J, Yoshita M, Kopidakis N, Hao X. Solar cell efficiency tables (version 57). Progress in Photovoltaics: Research and Applications. 2021 Jan 1;29(1):3-15. https://doi.org/10.1002/pip.3371

[3] Longeaud C. Study of transport parameters and defect states in thin film perovskites under different environments - air or vacuum - and after light-soaking. Guenier-Farret M, Alvarez J. EPJ Photovoltaics. 2020;11:5. https://doi.org/10.1051/epjpv/2019009

[4] Sonmezoglu S, Akin S. Suppression of the interface-dependent nonradiative recombination by using 2-methylbenzimidazole as interlayer for highly efficient and stable perovskite solar cells. Nano Energy. 2020;76:105127.

[5] Neophytou M, De Bastiani M, Gasparini N, Aydin E, Ugur E, Seitkhan A, Moruzzi F, Choaie Y, Ramadan AJ, Troughton JR. Enhancing the charge extraction and stability of perovskite solar cells using strontium titanate (SrTiO3) electron transport layer. ACS Applied Energy Materials. 2019;2(11):8090-8097.

[6] Ren A, Lai H, Hao X, Tang Z, Xu H, Jeco BMFY, Watanabe K, Wu L, Zhang J, Sugiyama M. Efficient Perovskite Solar Modules with Minimized Nonradiative Recombination and Local Carrier Transport Losses. Joule. 2020;4(6):1263-1277.

[7] Green MA, Dunlop ED, Hohl-Ebinger J, Yoshita M, Kopidakis N, Ho-Baillie AW. Solar cell efficiency tables (Version 55). Progress in Photovoltaics: Research and Applications. 2019 Dec 20;28(1):3-15. https://doi.org/10.1002/pip.3228

[8] N'Detigma K, Djicknoum D, Y. MS, Arouna D, Amadou SM. Module parameter extraction and simulation with LTSpice software model in sub-Saharan outdoor conditions. African Journal of Environmental Science and Technology. 2018 Dec 31;12(12):523-531. https://doi.org/10.5897/AJEST2018.2566

[9] Ibrahim H, Anani N. Evaluation of Analytical Methods for Parameter Extraction of PV modules. Energy Procedia. 2017 Oct;134:69-78.

https://doi.org/10.1016/j.egypro.2017.09.601

[10]

Tress W, Domanski K, Carlsen B, Agarwalla A, Alharbi EA, Graetzel M, Hagfeldt A. Performance of perovskite solar cells under simulated temperature-illumination real-world operating conditions. Nature energy. 2019;4(7):568-574. 
[11] Kata N, Diouf D, Darga A, Seidou Maiga A. The effect of the recombination mechanisms location on the temperature sensitivity of thin-film photovoltaic cells. EPJ Photovolt.. 2019;10. https://doi.org/10.1051/epjpv/2019008

[12] Schwenzer JA, Rakocevic L, Gehlhaar R, Abzieher T, Gharibzadeh S, Moghadamzadeh S, Quintilla A, Richards BS, Lemmer U, Paetzold UW. Temperature variation-induced performance decline of perovskite solar cells. ACS applied materials \& interfaces.

2018;10(19):16390-16399.

[13] Jošt M, Lipovšek B, Glažar B, Al-Ashouri A, Brecl K, Matič G, Magomedov A, Getautis V, Topič M, Albrecht S. Perovskite Solar Cells go Outdoors: Field Testing and Temperature Effects on Energy Yield. Advanced Energy Materials. 202005 28;10(25):2000454.

https://doi.org/10.1002/aenm.202000454 